\title{
Jacques Vicens: his life in research
}

\author{
Quentin Vicens ${ }^{1} \cdot$ Yang Kim $^{2}$ (D) J Jack Harrowfield ${ }^{3}$
}

Received: 9 April 2021 / Accepted: 13 May 2021 / Published online: 24 May 2021

(c) The Author(s), under exclusive licence to Springer Nature B.V. 2021

Jacques Vicens' two great intellectual passions were his art and his chemistry. For most of his life up until his retirement from the CNRS (the French Centre National de la Recherche Scientifique), when art became dominant, he pursued both with enormous enthusiasm and even published analyses of parallels between the two fields [1,2]. His independent research career as a chemist began with his exploration of organic chemistry in the solid state [3], chemistry which involved, amongst other species, phenols and phenolic resins and led to his introduction to the field of macrocyclic phenol-formaldehyde oligomers termed "calixarenes" then recently opened up by the fundamental work of David Gutsche $[4,5]$. Calixarenes quickly became Jacques' obsession (Fig. 1) and although his initial interest was in their capacity to act as receptors in the solid state [6], this progressed to studies of their solution properties which ultimately resulted in his seminal contributions to the application of calixarenes in nuclear waste treatment [7]. While a high point of his career, this involvement with the nuclear industry was far from its end and was followed by major developments into completely different areas such as those of calixdendrimers [8] and luminescent calixarenes [9].

The special character of Jacques as an individual was that he was not just focussed on his own contributions to chemistry but delighted in seeing what others could do to amplify it. This not only led to collaborations around the world but was also the basis of his editorial activities in the production of four books [10-13] where the panoply of continuing developments in calixarene chemistry were displayed. Much of his own work was of course described in these texts. His love of science and joy in creativity in general, allied to his natural modesty, made him a unique character in the contemporary world of competitive academia, one who is sorely missed by his many friends and colleagues.

The articles in this special edition of the Journal of Inclusion Phenomena and Macrocyclic Chemistry not only provide indices of the extent of Jacques' interests in chemistry and art but also reflect how as an individual his influence extended well beyond his own areas of research. The topics covered are of a truly remarkable range, from chemical synthesis and structure to art and medicine, comprising an exceptional tribute to the memory of Jacques. As editors, we must express our deepest gratitude to the numerous authors from all around the world who have made these contributions, carrying onward the torch of Jacques' objectives.

Yang Kim

ykim@kumamoto-u.ac.jp

Quentin Vicens

quentin.vicens@cuanschutz.edu

Jack Harrowfield

harrowfield@unistra.fr

1 Department of Biochemistry and Molecular Genetics, University of Colorado Denver School of Medicine, 12801 E. 17th Ave., RC1 South, Aurora, CO 80045, USA

2 IROAST, Kumamoto University, 2-39-1 Kurokami, Chuo-ku, Kumamoto 860-8555, Japan

3 ISIS, Université de Strasbourg, 8 allée Gaspard Monge, 67083 Strasbourg, France 
Fig. 1 Jacques Vicens and the four conformers of calix[4] arene on which he worked his magic of synthesis
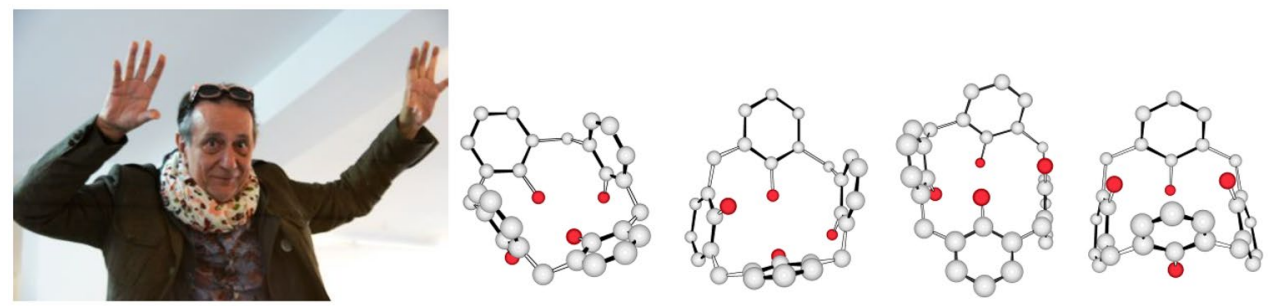

\section{References}

1. Vicens, J.: Art and chemistry: the topochemical principle and Las Meninas of Velazquez. J. Incl. Phenom. Macrocyclic Chem. 71(3-4), 275-279 (2011)

2. Vicens, J.: Machines in art and chemistry. J. Incl. Phenom. Macrocyclic Chem. 62(3-4), 383-387 (2008)

3. Lamartine, R., Perrin, R., Vicens, J.: Solid state organic chemistry: frontiers and prospects. Actualité Chimique 8, 7-14 (1984) (in French).

4. Gutsche, C.D., Muthukrishnan, R.J.: Analysis of the product mixtures produced by the base-catalyzed condensation of formaldehyde with para-substituted phenols. J. Org. Chem. 43, 4905-4906 (1978)

5. Gutsche, C.D.: In: Stoddart, J. F. (ed.) Calixarenes. Monographs in Supramolecular Chemistry No. 1. RSC Publishing, Cambridge (1989)

6. Vicens, J., Armah, A.E., Fujii, S., Tomita, K.I.: Separation of xylenes by extractive crystallization with calixarenes. J. Incl. Phenom. Mol. Recog. Chem. 10(1), 159-163 (1991)

7. Vicens, J.: Applied and fundamental research: their mutual stimulation in the real world of chemistry - developing calixbiscrowns for nuclear waste treatment. J. Incl. Phenom. Macrocyclic Chem. 55(9), 193-196 (2006)
8. Baklouti, L., Cheriaa, N., Mahouachi, M., Ben Othman, A., Abidi, R., Kim, J.S., Kim, Y., Vicens, J.: Calixarenes enhanced as dendrimers: a mini-review. Mini-Rev. Org. Chem. 3(3), 219-228 (2006)

9. Ben Othman, A., Mellah, B., Abidi, R., Kim, J.S., Kim, Y., Vicens, J.: Complexing properties of pyrenyl-appended calix[4] arenes towards lanthanides and transition metal cations. J. Incl. Phenom. Macrocyclic Chem. 97(3-4), 187-194 (2020)

10. Böhmer, V., Vicens, J. (eds.): Calixarenes - a Versatile Class of Macrocyclic Molecules. Kluwer Academic Press, Dordrecht (1991)

11. Asfari, Z., Vicens, J., Harrowfield, J. (eds.): Calixarenes; The 50th Anniversary. Kluwer Academic Publishers (1995)

12. Asfari, Z., Böhmer, V., Harrowfield, J., Saadioui, M., Vicens, J. (eds.): Calixarenes 2001. Kluwer Academic Publishers, Dordrecht (2001)

13. Vicens, J., Harrowfield, J. (eds.): Calixarenes in the Nanoworld. Springer, Dordrecht (2007)

Publisher's Note Springer Nature remains neutral with regard to jurisdictional claims in published maps and institutional affiliations. 